\title{
ALK NP_004295.2:p.F1245X
}

National Cancer Institute

\section{Source}

National Cancer Institute. ALK NP 004295.2:p.F1245X. NCI Thesaurus. Code C133466.

A change in the amino acid residue at position 1245 in the ALK tyrosine kinase receptor protein where phenylalanine has been replaced by another amino acid. 